\title{
EDITORIAL
}

\section{Jubileu de Ouro da Associação Brasileira de Enfermagem}

Com orgulho a Associação Brasileira de Enfermagem (ABEn) celebra, em 12 do corrente, o seu Jubileu de Ouro.

Os serviços prestados à profissão nestes 50 anos fazem dela a principal responsável pelo desenvolvimento da Enfermagem brasileira.

Foi fundada no Rio de Janeiro, em 12 de agosto de 1926, por um punhado de enfermeiras idealistas, diplomadas pela famosa escola, criada nessa cidade por iniciativa de Carlos Chagas, em 1923, hoje Escola de Enfermagem Ana Neri, da Universidade Federal do Rio de Janeiro.

Como todas as associações de classe, teve seus altos e baixos e passou por modificações profundas, inclusive na sua denominação.

Ao nascer foi batizada como Associação Nacional de Enfermeiras Diplomadas Brasileiras. Funcionou ativamente até o inícío da década de 40, quando hibernou. Tirou-a do casulo, em 1944, um grupo de enfermeiras de São Paulo, onde a enfermagem moderna se iniciara com a criação, em 1938, da Escola de Enfermeiras do Hospital São Paulo, e, em 1942, da Escola de Enfermagem de São Paulo (agora Escola Paulista de Enfermagem e Escola de Enfermagem da Universidade de São Paulo, respectivamente). Nesta segunda fase recebeu o nome de Associação Brasileira de Enfermeiras Diplomadas (ABED), que conservou até 1954, quando passou à presente denominação.

A vitabilidade do grupo que a criou traduz-se principalmente pela publicação de ANAIS DE ENFERMAGEM, a partir de 1932, hoje denominada REVISTA BRASILEIRA DE ENFERMAGEM, órgão oficial da Associação, e pela admissão desta, já em 1929, ao Conselho Internacional de Enfermeiras (ICN).

Foi a 19. associação a filiar-se ao ICN, a segunda da América Latina (a de Cuba precedeu-a de quatro anos) e a primeira da América do Sul. As exigências para ingresso no ICN eram poucas mas rígidas: determinado padrão de formação profissional das sócias e controle da associação exclusivamente por enfermeiras. Só 20 anos depois, em 1949, outra associação latino americana de enfermeiras (Haiti) conseguiria fiiiar-se ao ICN. 
Em 1955 filiou-se ao Comité Internacional Católico de Enfermeiras e Assistentes Médico-Sociais (CICIAMS) e em 1970 à Federação Pan-Americana de Enfermeiros, recém-criada.

A atuação da ABEn durante todos estes anos em favor da enfermagem e de seus profissionais foi e continua sendo ampla e intensa. $\mathrm{Na}$ falta de Sindicato de Enfermeiros e de Conselho de Enfermagem atuou ela tanto no campo cultural, que lhe é próprio, como no destes órgãos de classe.

A formação de profissionais, o aperfeiçoamento e o comportamento ético destes e a defesa de seus interesses, a melhoria das escolas e dos serviços de enfermagem e dos cuidados por estes prestados à população, a coleta de dados estatísticos sobre os profissionais, a divulgação da profissão, a representação da enfermagem junto aos Poderes Públicos e no exterior, com todos estes assuntos preocupou-se a ABEn.

O mais valioso instrumento de que a Associação se valeu para atingir seus objetivos foi a legislação federal, na qual concentrou grande parte de seus esforços. Nestes últimos 30 anos não houve projeto de lei de interesse da enfermagem que não recebesse sua atenção. Por intermédio do Executivo ou dos legisladores, conseguiu não só promover a promulgação de leis que julgava necessária (exemplo: a lei do exercício e a criação dos Conselhos Federal e Regionais de Enfermagem), como também substituir, emendar ou sustar $\mathrm{o}$ andamento de projetos que considerava inadequados ou nocivos à profissão ou aos profissionais. Sempre vigilante e sensível a tudo quanto afetasse a enfermagem, foi notável a atuação da ABEn neste campo, principalmente se forem levados em conta o número relativamente pequeno de seus membros e os obstáculos que tem encontrado pelo caminho.

A elevação do curso de enfermagem a nível superior, o enquadramento do enfermeiro como profissional liberal, a sua classificação no nível técnico-científico e tantas outras iniciativas bem sucedidas são fruto da dedicação e do dinamismo das Diretorias e Comissões que se sucederam desde 1926.

As realizações destes 50 anos, conseguidas à custa de trabalho e de lutas sem quartel, fazem da ABEn credora do respeito e da admiração de todos os enfermeiros brasileiros. (MRSP) 